\title{
CHANGING TRENDS IN CARCINOMA STOMACH - A CLINICO-PATHOLOGICAL CORRELATION
}

\author{
Paatneedi Naresh Kumar'1, Ravula Mahalakshmi², Gonugunta Sri Ranga Sai Karthik ${ }^{3}$
}

${ }^{1}$ Associate Professor, Department of General Surgery, Rangaraya Medical College.

2 Professor, Department of General Surgery, Rangaraya Medical College.

3Postgraduate Student, Department of General Surgery, Rangaraya Medical College.

ABSTRACT
BACKGROUND
The aim of this study is to study the incidence, age and sex distribution, commonest clinical presentation, stage at the time of
presentation, procedure performed and the outcome of carcinoma of stomach in the patients attending surgical wards in the
Government General Hospital, Rangaraya Medical College, Kakinada from August 2011 to September 2013.
Carcinoma of stomach has been described as "captain of men of death." It is the fourth most common cancer and the second
leading cause of cancer related deaths. Carcinoma of stomach is the most common gastrointestinal malignancy. Its incidence has
been increasing in the developing countries.

\section{MATERIALS AND METHODS}

A prospective study was conducted over 74 patients admitted to surgical wards with carcinoma stomach during August 2011 to September 2013.

\section{RESULTS}

Carcinoma stomach was more common in males between 50 - 70 years, most common presentation is pain abdomen followed by vomiting. It is common in patients with A + ve blood group. Most common site is antrum. Most of the patients presented with stage IV disease.

\section{CONCLUSION}

The most important factor in the prognosis of the patient with carcinoma stomach is the stage at the diagnosis and as most of the patients presented late (in advanced stage) they had poor prognosis. So screening by endoscopy in all the patients with symptoms and signs suggestive of carcinoma stomach for early detection should be carried out.

\section{KEYWORDS}

Changing Trends in Carcinoma Stomach, Epidemiological Study of CA Stomach.

HOW TO CITE THIS ARTICLE: Kumar PN, Mahalakshmi R, Karthik GSRS. Changing trends in carcinoma stomach - a clinicopathological correlation. J. Evolution Med. Dent. Sci. 2016;5(100):7361-7364, DOI: 10.14260/jemds/2016/1666

\section{BACKGROUND}

Carcinoma of stomach has been described as "captain of men of death." Carcinoma stomach is the $14^{\text {th }}$ most common cancer and cancer related death in United States, ${ }^{1}$ worldwide it is the fourth most common cancer and the second leading cause of cancer related death indicating its major prevalence in developing countries. Carcinoma of stomach is the most common gastrointestinal malignancy. Time Trends: In most countries gastric cancer has been declining since past 40 years. There is a greater decline among females compared to males. ${ }^{2}$ The overall mortality of gastric cancer is 3.7 deaths/100000 people, a decline of $35 \%$ since 1992.3,4

\section{MATERIALS AND METHODS}

A prospective study was conducted in GGH, Kakinada. The study period is from August 2011 to September 2013. The study sample consisted of 74 patients. Inclusion Criteria - All the patients admitted and who were diagnosed to have carcinoma stomach by HPE irrespective of comorbidities.

Financial or Other, Competing Interest: None.

Submission 14-10-2016, Peer Review 01-12-2016,

Acceptance 07-12-2016, Published 15-12-2016.

Corresponding Author:

Dr. Paatneedi Naresh Kumar,

\#10-5-27/1, Nageswar Rao St.

Ramaraopeta, Kakinada, Andhra Pradesh.

E-mail: drnaresh180532@yahoo.com

DOI: $10.14260 /$ jemds/2016/1666

\section{RESULTS}

The total number of admissions is $11,546 \%$ of Ca stomach admissions is $0.64 \%$.

Total number of gastrointestinal malignancy surgeries in the same time period are 162, of which surgeries for Ca stomach are 36 . Percentage $22.2 \%$.

Of the 74 cases studied, $56(76 \%)$ were males and 18 (24\%) were females. Male:female ratio is 3:1.

Maximum incidence is observed in the age group of $51-60$ yrs. Youngest person admitted was 18 years old and the oldest patient admitted was 87 years old.

The most common presenting symptom was pain abdomen in 57 cases (77\%) followed by vomiting and loss of appetite.

\section{Incidence of Symptoms}

\begin{tabular}{|c|c|c|c|}
\hline Sl. No. & Symptoms & No. of Cases & $\mathbf{\%}$ \\
\hline 1 & Pain abdomen & 57 & $77 \%$ \\
\hline 2 & Vomiting & 55 & $74 \%$ \\
\hline 3 & Loss of appetite & 40 & $54 \%$ \\
\hline 4 & Loss of weight & 40 & $54 \%$ \\
\hline 5 & Melena & 23 & $31 \%$ \\
\hline 6 & Dysphagia & 12 & $16 \%$ \\
\hline
\end{tabular}

Most common physical signs are palpable lump in 46 cases (62\%), anaemia in 57 cases (77\%) and hepatomegaly in 14 cases $(18 \%)$. 
Incidence of Signs

\begin{tabular}{|c|c|c|c|}
\hline Sl. No. & Physical Sign & No. of Cases & Percentage \\
\hline 1 & Palpable lump & 46 & $62 \%$ \\
\hline 2 & Anaemia & 57 & $77 \%$ \\
\hline 3 & Hepatomegaly & 14 & $18 \%$ \\
\hline 4 & Ascites & 18 & $24 \%$ \\
\hline 5 & VGP & 6 & $8 \%$ \\
\hline 6 & Virchow's Nodes & 11 & $15 \%$ \\
\hline 7 & $\begin{array}{c}\text { Distant Mets } \\
\text { (Krukenberg) }\end{array}$ & 1 & $1 \%$ \\
\hline
\end{tabular}

There is predominance in blood Group A.

\begin{tabular}{|c|c|c|}
\hline Blood Group & No. of Cases & Percentage \\
\hline A & 25 & $34 \%$ \\
\hline B & 20 & $30 \%$ \\
\hline O & 17 & $27 \%$ \\
\hline AB & 7 & $9 \%$ \\
\hline
\end{tabular}

Commonest site of growth is antrum, next common is body of stomach. Postop GJ stomal ulcer was observed in 5 cases. Malignant gastric ulcer perforation was encountered in 3 cases. Biopsy proved as adenocarcinoma later underwent subtotal gastrectomy. Many studies have shown increased incidence of gastric cancer in proximal stomach and decline in antral region 5,6 conflicting with the present study, which showed increased incidence of nonfundal lesions.

\begin{tabular}{|c|c|c|c|}
\hline Sl. No. & Site of Growth & No. of Cases & \% \\
\hline 1 & Fundus & 2 & $3 \%$ \\
\hline 2 & Fundus and Body & 3 & $4 \%$ \\
\hline 3 & Antrum and Body & 16 & $22 \%$ \\
\hline 4 & Antrum & 34 & $46 \%$ \\
\hline 5 & Body & 17 & $23 \%$ \\
\hline 6 & Entire Stomach & 2 & $3 \%$ \\
\hline
\end{tabular}

\section{Findings at Laparotomy}

More than $50 \%$ of the cases have lymph node involvement by the time of presentation. Pancreas is the common organ to be involved by direct infiltration.

\begin{tabular}{|c|c|c|c|}
\hline $\begin{array}{l}\text { Sl. } \\
\text { No. }\end{array}$ & Findings & $\begin{array}{l}\text { No. of } \\
\text { Cases }\end{array}$ & Percentage \\
\hline 1 & Invasion of Serosa & 48 & $65 \%$ \\
\hline 2 & $\begin{array}{c}\text { Lymph Node } \\
\text { Involvement } \\
\text { Perigastric, } \\
\text { Celiac and Splenic } \\
\text { Para-aortic }\end{array}$ & $\begin{array}{c}45 \\
22 \\
9\end{array}$ & $\begin{array}{l}60 \% \\
30 \% \\
12 \%\end{array}$ \\
\hline 3 & Liver Secondaries & 8 & $11 \%$ \\
\hline 4 & Ascites & 12 & $16 \%$ \\
\hline 5 & $\begin{array}{c}\text { Direct Infiltration } \\
\text { Liver } \\
\text { Pancreas } \\
\text { Transverse Colon }\end{array}$ & $\begin{array}{c}3 \\
10 \\
4\end{array}$ & $\begin{array}{c}4 \% \\
14 \% \\
5 \%\end{array}$ \\
\hline 6 & $\begin{array}{c}\text { Peritoneal } \\
\text { Secondaries }\end{array}$ & 10 & $14 \%$ \\
\hline
\end{tabular}

\section{Staging}

Most of the patients presented in Stage 4. In India, more than $98 \%$ of cases are diagnosed in advanced stage and in those subjected to surgery more than $70 \%$ have serosal infiltration. ${ }^{3}$

\begin{tabular}{|c|c|c|c|}
\hline Sl. No. & Stage & No. of Cases & Percentage \\
\hline 1 & I & 0 & $0 \%$ \\
\hline 2 & II & 13 & $18 \%$ \\
\hline 3 & IIIA & 51 & $20 \%$ \\
\hline 4 & IIIB & 7 & $9 \%$ \\
\hline 5 & IV & 39 & $53 \%$ \\
\hline
\end{tabular}

\section{Type of Surgery Adopted}

In $49 \%$ of cases we performed subtotal gastrectomy with gastrojejunostomy and jejunojejunostomy.

\begin{tabular}{|c|c|c|c|}
\hline $\begin{array}{c}\text { Sl. } \\
\text { No. }\end{array}$ & Surgery & $\begin{array}{c}\text { No. of } \\
\text { Cases }\end{array}$ & $\mathbf{\%}$ \\
\hline 1 & Radical Gastrectomy & 5 & $7 \%$ \\
\hline 2 & Subtotal Gastrectomy & 31 & $41 \%$ \\
\hline 3 & $\begin{array}{c}\text { Anterior } \\
\text { Gastrojejunostomy }\end{array}$ & 5 & $7 \%$ \\
\hline 4 & Feeding Jejunostomy & 14 & $19 \%$ \\
\hline 5 & No Laparotomy & 19 & $26 \%$ \\
\hline
\end{tabular}

\section{Histology}

Poorly differentiated carcinoma is commonly encountered.

\begin{tabular}{|c|c|c|c|}
\hline $\begin{array}{c}\text { Sl. } \\
\text { No. }\end{array}$ & $\begin{array}{c}\text { Nature of } \\
\text { Adenocarcinoma }\end{array}$ & $\begin{array}{c}\text { No. of } \\
\text { Cases }\end{array}$ & Percentage \\
\hline 1 & Well differentiated & 11 & $15 \%$ \\
\hline 2 & $\begin{array}{c}\text { Moderately } \\
\text { differentiated }\end{array}$ & 28 & $37 \%$ \\
\hline 3 & Poorly differentiated & 36 & $48 \%$ \\
\hline
\end{tabular}

Of the 74 cases 36 patients underwent gastrectomy, 28 patients (38\%) have survived for average period of one and a half to two years; 17 patients (23\%) were alive, under followup. Remaining patients with advanced carcinoma have survived for an average period of 9 months.

\section{DISCUSSION}

In the present study, the incidence of carcinoma stomach is more in males $3: 1)$ comparable with other studies, also showing increased incidence of carcinoma stomach in males.

\section{Sex Incidence}

\begin{tabular}{|c|c|c|}
\hline Study & Males & Females \\
\hline M. A. Kabir, R. Barua Study & $64 \%$ & $36 \%$ \\
\hline Present Study & $76 \%$ & $24 \%$ \\
\hline
\end{tabular}

\section{Age Incidence}

Maximum incidence is observed in the age group of $51-60$ years, which correlated with the study conducted at Tata Memorial Hospital, Mumbai.

M. A. Kabir, R. Burua and H. Musad - $2011^{7}$ study showed that average age of diagnosis of carcinoma of stomach is 51 plus or minus 14 years.

\section{Incidence of Symptoms and Signs}

Common symptoms are vomiting and pain abdomen. Common signs are anaemia and palpable lump. 


\begin{tabular}{|c|c|c|c|c|}
\hline $\begin{array}{c}\text { Sl. } \\
\text { No. }\end{array}$ & Symptoms & $\begin{array}{c}\text { No. } \\
\text { of } \\
\text { Cases }\end{array}$ & $\begin{array}{c}\text { \% } \\
\text { (Present } \\
\text { Study) }\end{array}$ & $\begin{array}{c}\text { M. A. Kabir, } \\
\text { R. Barua } \\
\text { Study }\end{array}$ \\
\hline 1 & $\begin{array}{c}\text { Pain } \\
\text { Abdomen }\end{array}$ & 57 & $77 \%$ & $100 \%$ \\
\hline 2 & Vomiting & 55 & $74 \%$ & $78 \%$ \\
\hline 3 & $\begin{array}{c}\text { Loss of } \\
\text { Appetite }\end{array}$ & 40 & $54 \%$ & $36 \%$ \\
\hline 4 & $\begin{array}{c}\text { Loss of } \\
\text { Weight }\end{array}$ & 40 & $54 \%$ & $62 \%$ \\
\hline 5 & Melena & 23 & $31 \%$ & $23 \%$ \\
\hline 6 & Dysphagia & 12 & $16 \%$ & $24 \%$ \\
\hline
\end{tabular}

There is predominance in blood group A. Peter J. D. Adamo, ND 2000 - 2009 study declared that blood group A is associated with increased risk of gastric cancer.

\section{Incidence in Various Blood Groups}

\begin{tabular}{|c|c|c|c|}
\hline $\begin{array}{c}\text { Blood } \\
\text { Group }\end{array}$ & $\begin{array}{c}\text { No. of } \\
\text { Cases }\end{array}$ & $\begin{array}{c}\text { Percentage } \\
\text { (Present Study) }\end{array}$ & $\begin{array}{c}\text { H. Masud, } \\
\text { R. Burua Study }\end{array}$ \\
\hline $\mathrm{A}$ & 25 & $34 \%$ & $34 \%$ \\
\hline $\mathrm{B}$ & 20 & $30 \%$ & $22 \%$ \\
\hline $\mathrm{O}$ & 17 & $27 \%$ & $28 \%$ \\
\hline $\mathrm{AB}$ & 7 & $9 \%$ & $16 \%$ \\
\hline
\end{tabular}

\section{Anatomical Site}

Most of the tumours are from antral region and is comparable to the study of Waisberg J, Andre EA, Franco MI study 2006.

\section{Anatomical Distribution of Lesion}

\begin{tabular}{|c|c|c|}
\hline Site of Growth & $\begin{array}{c}\text { M. A. Kabir, } \\
\text { R. Barua Study }\end{array}$ & $\begin{array}{c}\text { Present } \\
\text { Study }\end{array}$ \\
\hline Fundus & $4 \%$ & $3 \%$ \\
\hline Fundus and Body & $4 \%$ & $4 \%$ \\
\hline Antrum and Body & $24 \%$ & $22 \%$ \\
\hline Antrum & $50 \%$ & $46 \%$ \\
\hline Body & $18 \%$ & $23 \%$ \\
\hline Entire Stomach & $0 \%$ & $3 \%$ \\
\hline
\end{tabular}

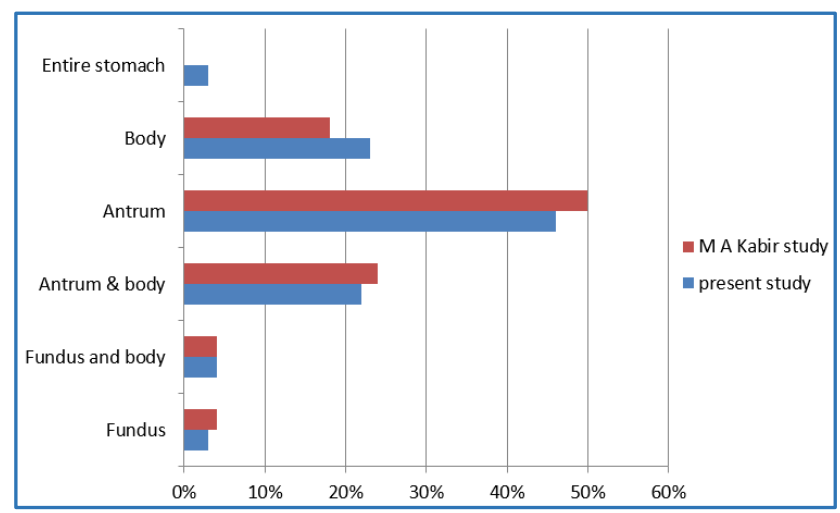

In $49 \%$ of cases, we performed subtotal gastrectomy with gastrojejunostomy and jejunojejunostomy. It is same as the study conducted by M Sika S, Tazima, Benhamiche AM Br J. Surg 1997. They stated as proportion of curative resections in $50 \%$.

36 patients underwent curative resection, out of which 6 patients died postoperatively. Operative mortality is $16.6 \%$. M
Sika S, Tazima, Benhamiche AM Br J. Surg 1997 study gave operative mortality as $13.6 \%$.

Post-operative biopsies were studied and poorly differentiated adenocarcinoma is commonly encountered.

Differentitation of Malignancy

\begin{tabular}{|c|c|c|}
\hline $\begin{array}{c}\text { Nature of } \\
\text { Adenocarcinoma }\end{array}$ & $\begin{array}{c}\text { IGOR Rabin, } \\
\text { Andronik Kapiev } \\
\text { and Barachikman } \\
\text { Study }\end{array}$ & $\begin{array}{c}\text { Present } \\
\text { Study }\end{array}$ \\
\hline Well Differentiated & $8.3 \%$ & $15 \%$ \\
\hline $\begin{array}{c}\text { Moderately } \\
\text { Differentiated }\end{array}$ & $50 \%$ & $37 \%$ \\
\hline $\begin{array}{c}\text { Poorly } \\
\text { Differentiated }\end{array}$ & $41.7 \%$ & $48 \%$ \\
\hline
\end{tabular}

All the patients in this study were advised chemotherapy with Inj. 5FU and Inj. Leucovorin. Inj. 5FU $500 \mathrm{mg}$ IV in 5\% dextrose from day 1 to 5 were given once in 28 days; before starting each cycle of chemotherapy $\mathrm{Hb} \%$, TLC and Platelet count were estimated. If low counts were detected, the cycle was skipped and arrangements were made for blood transfusion. Minimum of 6 cycles of chemotherapy were given.

Of the 74 cases, 36 (49\%) underwent gastrectomy; 28 (38\%) survived for an average period of one and a half to two years; 17 (23\%) patients were alive in followup. Remaining patients with advanced disease (51\%) had survived an average period of 9 months. Shiraishi N, Satok, Yasoda K, J. Surg Oncol 2007 study stated median survival period of who underwent gastrectomy in 15 months.

\section{CONCLUSION}

A total of 74 cases were diagnosed in a 2-year period.

There is male predominance. Male: Female ratio, 3:1.

More than $80 \%$ of cases were in the age group of $41-70$ yrs.

Blood Group A constitute most of the cases.

Duration of symptoms varied between 1 month and 9 months.

Pain abdomen and vomiting are presenting symptoms in most of the cases.

Early gastric carcinomas were not detected in our series. Most of the cases were advanced carcinomas.

Pyloric antrum was involved in $2 / 3^{\text {rd }}$ of the cases.

Curative resection was done in $1 / 2$ of the cases and others underwent palliative procedures.

Patients with curative resection survived for an average period of 18 months; those without any procedure survived for a period of 6 months.

\section{Proposals}

Half of the cases were admitted in late stages, so curative resection was possible only in half of the cases.

Serious attempts should be made to detect gastric cancer in early stages when it is potentially curable.

For this gastroscopy, facilities should be improved and trained personnel in gastroscopic diagnosis and cytological examination should be available in all community area hospitals and district hospitals. 
To improve the prognosis, all dyspeptic patients above 40 years should be viewed with suspicion and subjected to thorough investigation and followup.

\section{REFERENCES}

1. Jemla A, Siegel R, Ward E, et al. Cancer statistics, 2009. CA Cancer J Clin 2009;59(4):225-49.

2. Jassawalla DJ, Yeole BB, Netekar MV. Cancer incidence in Indian Christians. Br J cancer 1985;51(6):883-91.

3. National cancer institute, surveillance research programme: fast stats 2009 http://seer.cancer.gov/faststats.

4. Mohandas KM, Nagral A. Epidemiology of digestive tract cancer in India. Indian journal of gastroenterology 1998;17:100-3.
5. Blot WJ, Devesa SS, Kneller RW, et al. Rising incidence of adenocarcinoma of the esophagus and gastric cardia. The Journal of the American Medical Association 1991;265(10):1287-9.

6. Kelley JR, Duggan JM. Gastric cancer epidemiology and risk factors. Journal of Clinical Epidemiology 2003;56(1):1-9.

7. Kabir MA, Barua R, Masud H, et al. Clinical presentation, histological findings and prevalence of helicobacter pylori in patients of gastric carcinoma. Faridpur Med Coll J 2011;6(2):78-81. 